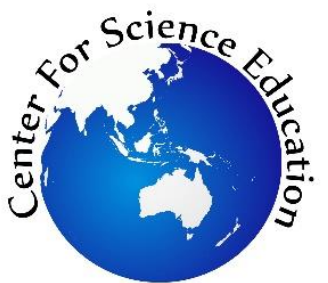

Tersedia online di EDUSAINS

Website: http://journal.uinjkt.ac.id/index.php/edusains

EDUSAINS, 13(1), 2021, 8-14

Research Artikel

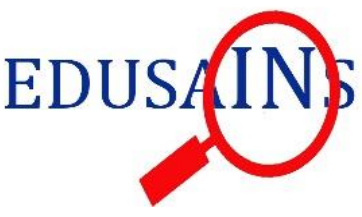

\title{
GENDER DIFFERENCES IN THE RELATIONSHIP BETWEEN ANXIETY, SELF- EFFICACY AND STUDENTS LEARNING OUTCOMES ON CHEMISTRY SUBJECT
}

\section{PERBEDAAN GENDER DALAM HUBUNGAN ANTARA KECEMASAN, EFIKASI DIRI DAN HASIL BELAJAR SISWA PADA MATA PELAJARAN KIMIA}

\author{
Siti Amaliyah", Siti Suryaningsih, Luki Yunita \\ Pendidikan Kimia, Fakultas Ilmu Tarbiyah dan Keguruan, UIN Syarif Hidayatullah Jakarta, Indonesia \\ sitiamaliyah1995@gmail.com
}

\begin{abstract}
Learning outcomes of male and female students have different results. Psychological factors in chemistry subjects including anxiety and self-efficacy as factors related to each other. The purpose of this study was to determine the relationship of anxiety and self-efficacy of the chemistry learning outcomes of class $X$ science students related to gender in two public high schools in South Tangerang city for the academic year of 2017/2018. This is a correlational study using a quantitative approach. The population in this study involved 300 students selected through a purposive sampling method which resulted in 161 students relevant to this study including 87 females and 74 males students. The instruments used in the study were anxiety questionnaires and self-efficacy questionnaires with 30 items on each questionnaire, and also for collecting learning outcomes data middle test scores. The results showed the value of sig. $0,00<\alpha(0,025)$ which of $H_{0}$ is rejected and $H_{1}$ is accepted. The coefficient of determination $\left(R^{2}\right)$ shows the percentage contribution of influence on male $26.11 \%$ and female $37.08 \%$ which can be concluded that there is a relationship between anxiety and self-efficacy towards learning outcomes of chemistry male students have a smaller contribution than female students. Replication of the study in different science disciplines and comparing science and non-science majors are also recommended.
\end{abstract}

Keywords: anxiety; self-efficacy; learning outcomes on chemistry subject; gender

\begin{abstract}
Abstrak
Hasil belajar siswa laki-laki dan siswa perempuan mempunyai perbedaan capaian hasil akhir. Pada pelajaran kimia faktor psikologi meliputi kecemasan dan self-efficacy menjadi faktor yang berhubungan satu dengan yang lain. Tujuan penelitian ini untuk mengetahui hubungan kecemasan dan self-efficacy terhadap hasil belajar kimia siswa kelas X IPA berkaitan dengan perbedaan gender pada dua sekolah Sekolah Menengah Atas Negeri di Tangerang Selatan tahun ajaran 2017/2018. Penelitian ini merupakan penelitian korelasional dengan pendekatan kuantitatif. Populasi berjumlah 300 siswa dengan penarikan sampel purposive sampling sejumlah 161 siswa meliputi 87 siswa perempuan dan 74 siswa laki-laki. Instrumen yang digunakan berupa angket kecemasan dan self-efficacy sejumlah 30 butir pernyataan pada masing-masing angket serta data hasil belajar berupa nilai Ujian Tengah Semester. Hasil penelitian menunjukkan nilai sig. $0,00<\alpha(0,025)$ dimana $\mathrm{H}_{0}$ ditolak dan $\mathrm{H}_{1}$ diterima. Koefisien determinasi $\left(\mathrm{R}^{2}\right)$ menunjukkan presentase kontribusi pada hubungan yang disumbangan secara simultan pada siswa laki-laki lebih kecil sebesar $26,11 \%$ dari siswa perempuan sebesar 37,08\% sehingga secara keseluruhan dapat disimpulkan bahwa hubungan antara kecemasan dan self-efficacy terhadap hasil belajar kimia pada siswa laki-laki mempunyai sumbangan lebih kecil dari siswa perempuan dengan capaian hasil belajar yang lebih tinggi. Replikasi studi dalam disiplin ilmu yang berbeda dan membandingkan jurusan sains dan non-sains juga dianjurkan.
\end{abstract}

Kata Kunci: kecemasan; self-efficacy; hasil belajar kimia; jenis kelamin

Permalink/DOI: http:// doi.org/10.15408/es.v13i1.12991

*Corresponding author 


\section{INTRODUCTION}

Chemistry has a very broad scope, both descriptively and theoretically, has made students feel difficulties which have an impact on student learning outcomes that are lacking satisfactory. The success of learning in the cognitive domain is also influenced by affective conditions of students. The affective domain determines a person's learning success. The successful of learning process can bring positive changes to individuals in cognitive, affective and psychomotor aspects to achieve educational goals through interaction with their environment.

Study from Purwanto (2016) explains about learning outcomes as a teaching and learning process to achieve educational goals. As a knowledge parameter for students who have been taught, the results of self-learning are often used as a measurement for achieving the objectives of learning.

The problem of the study was some students feel afraid of chemistry subject because it is perceived as a difficult subject to learn (Woldeamanuel et al., 2013). Another study conducted by Ristiyani \& Bahriah, (2016) stated that psychological factors accounted about $69.78 \%$ with moderate categories in terms of learning difficulties on chemistry subjects. It makes the student learning outcomes unsatisfactory and it also reduces students' interest in learning chemistry. Stoneberg (2017) was found relating reduction in students' chemistry learning achievements from 2015 to 2017. It makes learning outcomes as a focus and universal problem on the most widely conducted research in education.

Gender is one of the factors that can influence student academic achievement, especially in science subjects this study conducted by Joseph et al. (2015). Based on those studies, male and females students have different learning outcomes. Further more Dianabasi \& Diwa (2017) stated anxiety and selfefficacy as non-cognitive factors could increase or decrease student learning outcomes with cognitive factors as a previously studied.

Student usually feels anxiety when they are evaluating by teachers, during exam or giving public performances. In learning context anxiety can affect the ability of receiving information, its processing, and retrieving it when it's necessary (Ehsan \& Ehsan, 2014). Anxiety as a state of fear that persists and is characterized by feelings of worry and anxiety, concern, difficulty in concentration and symptoms of motor tension (Wade, 2007) defined. Students' anxiety makes the learning process became less optimal and affect their achievement of learning outcomes on chemistry subject.

Students' anxiety affects negatively on student learning and reduces their learning activities. However, students' anxiety usually effects become learning facilitation by motivating students to adjust new situations (Yaman, 2010). Nurlaila (2017) stated the dynamic of anxiety coming from cognitive events caused by the negative perception of selfcompetence including feeling unprepared, feeling unable to face the test, and unable to control physical responses which made students feeling anxious. besides the study from Woldeamanuel et al. (2013) found female students had higher anxiety than male students on chemistry subjects.

Self-efficacy as an assessment of an individual's ability to carry out behavior or to achieve certain goals by (Ormrod, 2008). Every individual might get high or low self-efficacy. Students with higher self-efficacy will more diligent, slightly anxious and they never get experience with depression. Meanwhile, individuals with low selfefficacy have less social skills, anxiety on the responses to their environment, intention to avoid interpersonal interactions and tend to be more depressed (Nurlaila, 2017). The research conducted by Shkullaku (2013) was found that women have lower self-efficacy than men in terms of receiving, it could be means men who have higher self-efficacy show high academic performance because they feel confident with their competence.

Several studies related of anxiety, selfefficacy and learning outcomes have been carried out before including research by Osman \& Mehmet (2015); Disai et al. (2017); Utami \& Nurjati (2018) conducted on biology, mathematics and English subjects. The study produced data on the correlation between anxiety, self-efficacy and learning outcomes based on gender. The research led to this study which focused on the subject of chemistry in 
the classroom with the variables of anxiety and selfefficacy as factors related to student chemistry learning outcomes in the classroom by looking at gender differences in these correlations.

Research on anxiety and self-efficacy towards based gender learning outcomes especially in chemistry learning is needed in the learning process. Therefore, it is necessary to do research focusing on gender differences in the relationship of anxiety and self-efficacy towards student chemistry learning outcomes.

\section{METHOD}

This study uses a correlation method with a quantitative approach. According to Creswell (2016) this type of research is non-experimental (correlational design) using statistical correlation to describe and measure the degrees or the relationships between two variables.

The study used a purposive sampling technique based on predetermined criteria covering the whole process of learning chemistry in class which is followed by grade $10^{\text {th }}$ students as well as student involvement in laboratory practice and application in everyday life with 161 students consisting of 87 female students and 74 male students who were relevant as the sample of the study.

The anxiety instrument used in this study is an anxiety questionnaire developed from Wahid et al. (2014) which divides three factors in anxiety including emotional factors, assessment factors and environmental factors. The self-efficacy questionnaire used in this study was developed from Suprapto et al. (2017) with 30 items representing six domains in self-efficacy. Both of the instruments had been translated into Indonesian language and had passed the validity test from the expert lecturers. The results of the validity test on each anxiety and selfefficacy instrument as many as 30 items were declared valid and ready to be used. The results obtained from the reliability test on the anxiety instrument were 0.714 and the self-efficacy instrument was 0.736 with a very reliable category on each. each instrument as many as 30 items are declared reliable.
Furthermore, the students as respondents were asked to fill out the questionnaire by giving a checkmark $(\sqrt{ })$ to the answer that was considered relevant to their cases. Whereas in the collection of chemistry learning outcomes, the data were in the form of the Middle Exam result of chemistry subject for the even semester of the academic year 2017/2018 through the documentation method.

Each variable (anxiety, self-efficacy and learning outcomes) is categorized by average. Then, the Kolmogorov-Smirnov normality test was conducted to determine whether the sample was normally distributed and the homogeneity Levene test was also done to determine the distribution of the sample homogeneous.

Hypothesis testing uses multiple correlation tests to determine the degree or strength of the relationship between three variables, and to determine the contribution by variables $\mathrm{X}_{1}$ and $\mathrm{X}_{2}$ toward of variable $Y$ and contribute partially given by variables $X_{1}$ toward $Y$ and $X_{2}$ toward variable $Y$ (Siregar, 2017). Overall of the data analysis used by SPSS version 22 software with a significance level of $5 \%(\alpha=0.05)$.

\section{RESULT AND DISCUSSION}

This study showed an average for the variable of student's anxiety with a result amount $(\bar{x}=83.73)$ was lower than female students $(\bar{x}=85.46)$ in the very high category. This showed that female students were more anxious than male students. While the variable self-efficacy found that the average of the male student $(\bar{x}=95.05)$ was higher than the female students $(\bar{x}=91.66)$ in the very high category. While the chemistry learning outcomes, the data showed that the male students had better chemistry learning outcomes with an average $(x=$ $80.43)$ than the female students on average $(\bar{x}=$ 78.34). The results of hypothesis testing can be explained below:

\section{Correlation Between Anxiety And Learning Outcomes on Chemistry Subjects Based Gender}


The results of the correlation test of anxiety variables with chemistry learning outcomes based on gender can be showed in Table 1 .

Table 1. correlation between student's anxiety and chemistry learning outcomes based on gender

\begin{tabular}{llll}
\hline Gender & $\begin{array}{l}\text { Sig } \\
\text { Change }\end{array}$ & $\begin{array}{l}\text { Pearson } \\
\text { correlation }\end{array}$ & $\boldsymbol{\alpha}$ \\
\hline $\begin{array}{l}\text { Male } \\
\text { students }\end{array}$ & 0,000 & -0.443 & 0,025 \\
$\begin{array}{l}\text { Female } \\
\text { students }\end{array}$ & 0,000 & $-0,456$ & \\
\hline
\end{tabular}

According to the results of the correlation test above was found the significance between male and female students was $0,000<\alpha(0,025)$, where $\mathrm{H}_{0}$ was rejected so it could be concluded that there was a relationship between students' anxiety and chemistry learning outcomes both male and female students. The relationship between anxiety and learning outcomes was included in the negative correlation, this shows that anxiety increases the student's chemistry learning outcomes decline and vice versa. this is in line with research conducted by Ali \& Mohsin (2013); Kurbanoğlu \& Nefes (2016) which states that anxiety can affect learning outcomes as a result of the resulting negative impact.

The test results of the correlation between anxiety relationship with the chemistry learning outcomes on the chemistry subject of female students were higher than male students means male student learning outcomes better than female students. In this case, if the anxiety of female students is high it will have a negative impact which results in poor chemistry learning outcomes. This is following the findings from Woldeamanuel et al. (2013) which explained that female students have high anxiety in chemistry lessons and the result were reinforced by the study from Fard (2013) who found that women have high anxiety so that it can inhibit the achievement of learning outcomes obtained.

\section{Correlation between Self-efficacy and chemistry learning outcomes based on Gender}

The result of self-efficacy variable with chemistry learning outcomes based gender can be showed in Table 2.

Table 2. Correlation between self-efficacy and chemistry learning outcomes based on gender

\begin{tabular}{llll}
\hline Gender & $\begin{array}{l}\text { Sig } \\
\text { Change }\end{array}$ & $\begin{array}{l}\text { Pearson } \\
\text { correlation }\end{array}$ & $\boldsymbol{\alpha}$ \\
\hline $\begin{array}{l}\text { Male } \\
\text { Students }\end{array}$ & 0,000 & 0,539 & 0,025 \\
$\begin{array}{l}\text { Female } \\
\text { Students }\end{array}$ & 0,000 & 0,621 & \\
\hline
\end{tabular}

According to the results of the correlation test above was found that male students have $0.001<\alpha$ $(0.025)$ and female students have $0.00<\alpha(0.025)$ with $\mathrm{H}_{0}$ was rejected. This can be interpreted that there is a relationship between Self-efficacy and student chemistry learning outcomes. The relationship between Self-efficacy and learning outcomes of chemistry students was included in a positive correlation. It is called a positive correlation if two correlated variables run parallel, meaning that the relationship between the two variables shows the same direction. Thus it can be concluded when students' self-efficacy increases, students' chemistry learning outcomes decline.

The current study found that higher selfefficacy will have a good impact on students' chemistry learning outcomes. These results are in line with the research conducted by Jansen et al. (2015); Uzuntiryaki-Kondakci \& Senay (2015); Villafañe \& Lewis (2016); Ramnarain \& Ramaila (2018) on chemistry subject that showed a positive relationship between self-efficacy and learning outcomes on chemistry subject. Self-efficacy can influence learning outcomes on chemistry subjects. In this case, self-efficacy can lead become selfconfidence and optimism of students in undergoing the activity process of chemistry learning in the classroom, especially when working on assignments and evaluations given by the teacher despite all difficulties. This was confirmed by Rosyida et al. (2018) in their study that students with low selfconfidence will be pessimistic and unable to complete tasks, while students with high selfconfidence will be optimistic and can complete the task well.

\section{Correlation between students anxiety and Self- efficacy based Gender}

The result of students anxiety variable and self-efficacy variable based gender can be showed in Table 3. 
Table 3. Correlation between students anxiety and Selfefficacy based Gender

\begin{tabular}{llll}
\hline Gender & $\begin{array}{l}\text { Sig } \\
\text { Change }\end{array}$ & $\begin{array}{l}\text { Pearson } \\
\text { correlation }\end{array}$ & $\boldsymbol{\alpha}$ \\
\hline $\begin{array}{l}\text { Male } \\
\text { Students }\end{array}$ & 0,019 & -0.273 & \\
$\begin{array}{l}\text { Female } \\
\text { Students }\end{array}$ & 0,003 & $-0,310$ & 0,025 \\
\hline
\end{tabular}

Based on the result of the correlation test above, it can be seen that the significance of male students is $0.019<\alpha(0.025)$ and female students $0.003<\alpha(0.025)$, with $\mathrm{H} 0$ is rejected. Thus there is a relationship between self-efficacy and male and female students. These results are in line with previous studies conducted by Disai et al. (2017) on math subject which showed a significant negative relationship between anxiety and self-efficacy. Related research was conducted by Deviyanthi \& Widiasavitri (2016) showed a negative relationship between anxiety and self-efficacy. It means that the relationship between the two variables is in the opposite direction, which means if the student's anxiety high, self-efficacy will be low and vice versa if anxiety is low then self-efficacy is high.

However, the study also found that although students experience anxiety on chemistry subjects, students do not feel that anxiety is a feeling that can shake their performance in the process of learning chemistry. This is also supported by student learning outcomes in the high category. Students with low self-efficacy tend to avoid difficult tasks because of the low level of confidence in completing a job.

\section{Correlation between students anxiety and Self- efficacy toward chemistry learning outcomes based on gender}

The result of the student's anxiety variable and self-efficacy variable toward chemistry learning outcomes based on gender can be shown in Table 4 .

Table 4. The result of student's anxiety and self-efficacy toward chemistry learning outcomes based on gender

\begin{tabular}{llll}
\hline Gender & $\begin{array}{l}\text { Sig } \\
\text { Change }\end{array}$ & $\begin{array}{l}\text { F } \\
\text { Pearson } \\
\text { correlation }\end{array}$ & $\begin{array}{l}\text { Determin } \\
\text { ation test }\end{array}$ \\
\hline $\begin{array}{l}\text { Male } \\
\text { students }\end{array}$ & 0,000 & 0,539 & $26,11 \%$ \\
$\begin{array}{l}\text { Female } \\
\text { students }\end{array}$ & 0,000 & 0,621 & $37,08 \%$ \\
\hline
\end{tabular}

\section{A $\quad 0,025$}

Based on Table 4 above, it can be seen that the significance of male and female students is the same namely $0.00<\alpha(0.025)$, where $\mathrm{H} 0$ is rejected. Thus there is a relationship between anxiety and selfefficacy on student chemistry learning outcomes both in male and female students.

The relationship between anxiety and selfefficacy towards student chemistry learning outcomes is included in the group of positive correlations. So that it can be concluded based on the multiple correlation test that has been done, there is a relationship between anxiety and self-efficacy towards student chemistry learning outcomes. These results are in line with the research conducted by Cuevas \& Berou (2019) which states that there is a relationship between anxiety and self-efficacy towards learning outcomes obtained but not significantly between male and female students. Besides, the results of Mohammadyari (2013) stated that the relationship between anxiety and selfefficacy towards learning outcomes showed that men were superior to women. This is because the results of the correlation of anxiety and self-efficacy can almost be accompanied by high learning outcomes even though the lowest scores are found in female students. The results are also supported by a higher determination coefficient for female students of $37.08 \%$ of male students of $26.11 \%$.

\section{CONCLUSIONS}

According to the data that resulted in the current study, it can be seen that gender differences in correlation between anxiety and self-efficacy towards chemistry learning outcomes show significant results with a higher determination coefficient on female students of $37.08 \%$ of male students of $26.11 \%$. So it is concluded that anxiety and self-efficacy can be the factors that are associated with a decrease in student learning outcomes particularly gender differencess. The data shows that female has high anxiety than male, but it can be balanced with high self-efficacy so that the effect on learning outcomes is good, while male has lower anxiety with lower self-efficacy than female, 
this affects achievement of learning outcomes was not good.

\section{REFERENCES}

Ali, M. S., \& Mohsin, M. N. (2013). Relationship of Test Anxiety With Students 'Achievement in Science. 3(1), 99-106.

Creswell, J. W. (2016). Research Design: Pendekatan Metode Kualitatif, Kuantitatif Dan Campuran Edisi 4. Yogyakarta: Pustaka Belajar.

Cuevas, M. M., \& Berou, M. (2019). Students Mathematics Self-Efficacy and Anxiety as Correlates to Academic Performance. University of Bohol Multidisciplinary Research Journal, 4(1), 1-18.

Deviyanthi, N. M. F. S., \& Widiasavitri, P. N. (2016). Hubungan Antara Self-Efficacy dengan Kecemasan Komunikasi dalam Mempresentasikan Tugas di Depan Kelas Ni Made Ferra Sarah Deviyanthi dan Putu Nugrahaeni Widiasavitri. Jurnal Psikologi Udayana, 3(2), 342-353

Dianabasi, E. J., E, U. I., \& Diwa, O. B. (2017). Psychological Factors and Secondary School's Students Academic Performance in Mathematics. IOSR Journal of Research \& Method in Education (IOSRJRME), 7(02), 06-13.

Disai, W. I., Dariyo, A., \& Basaria, D. (2017). Hubungan antara kecemasan matematika dan self-efficacy dengan hasil belajar matematika siswa SMA X kota Palangkaraya. Jurnal Muara Ilmu Sosial, Humaniora, dan Seni, 1(2), 556.

Ehsan, D., \& Ehsan, D. (2014). The effect of anxiety and emotional intelligence on students learning process faculty of human ecology. Journal of Education \& Social Policy, 1(2), $115-122$

Fard, M. B. (2013). An Investigation into the Relationship Among Self-Efficacy, SelfEsteem, Test Anxiety and Final Achievement of English Literature Students. Journal of
Studies in Learning and Teaching English, 1(3), 121-138.

Jansen, M., Scherer, R., \& Schroeders, U. (2015). Students' self-concept and self-efficacy in the sciences: Differential relations to antecedents and educational outcomes. Contemporary Educational Psychology. Contemporary Educational Psychology 41, 13-24.

Joseph, A., John, O., Eric, I., Yusuf, S., \& Olubunmi, A. (2015). Effect of Gender on Students , Academic Performance in Computer Studies in Secondary Schools in New Bussa, Borgu Local Government of Niger State. Journal of Education and Practice 6(33), 1-7.

Kurbanoğlu, N. İ., \& Nefes, F. K. (2016). Contextbased questions in science education: Their effects on test anxiety and science achievement in relation to the gender of secondary school students. Journal of Baltic Science Education 15(3,) 382-390.

Mohammadyari, G. (2013). Comparative Study of Relationship between General Perceived Self-efficacy and Test Anxiety with Academic Achievement of Male and Female Students. Procedia - Social and Behavioral Sciences (2012) 69 2119-2123.

Nurlaila, S. (2017). Pelatihan Efikasi Diri Untuk Menurunkan Kecemasan Pada Siswa-Siswi Yang Akan Menghadapi Ujian Akhir Nasional. Guidena: Jurnal Ilmu Pendidikan, Psikologi, Bimbingan dan Konseling 1(1) 1.

Ormrod, E. J. (2008). Psikologi Pendidikan: membantu siswa tumbuh da berkemban, jilid 2. Jakarta: Penerbit Erlangga.

Osman, C., \& Mehmet, Y. (2015). Evaluating high school students anxiety and self-efficacy towards biology. Educational Research and Reviews, 10(7), 987-993.

Purwanto. (2016). Evaluasi Hasil Belajar. Yogyakarta: Pustaka Pelajar.

Ramnarain, U., \& Ramaila, S. (2018). The relationship between chemistry self-efficacy of South African first year university students 
and their academic performance. Chemistry Education Research and Practice, 19(1), 6067.

Ristiyani, E., \& Bahriah, E. S. (2016). Analisis Kesulitan Belajar Kimia Siswa Di Sman X Kota Tangerang Selatan. Jurnal Penelitian dan Pembelajaran IPA 2(1), 18.

Rosyida, F., Utaya, S., \& Budijanto, B. (2018). Pengaruh Kebiasaan Belajar dan Self-Efficacy terhadap Hasil Belajar Geografi Di SMA. Jurnal Pendidikan Geografi, 21(2), 17-28.

Shkullaku, R. (2013). www.euacademic.org The Relationship between Self - efficacy and Academic Performance in the Context of Gender among Albanian Students. European Academic Research 1(4), 467-478.

Siregar, S. (2017). Metode Penelitian Kuantitatif Dilengkapi dengan Perbandingan Perhitungan Manual dan SPSS Versi 17. Jakarta: Kencana Persada Media Group.

Stoneberg, B. D. (2017). Biology and Chemistry Achievement In Idaho High Schools. K-12 Reseacrch Idaho 1-9.

Suprapto, N., Chang, T. S., \& Ku, C. H. (2017). Conception of learning physics and selfefficacy among indonesian university students. Journal of Baltic Science Education 16(1), 7-19.

Utami, L. H., \& Nurjati, L. (2018). Hubungan SelfEfficacy, Belief dan Motivasi dengan
Kecemasan Mahasiswa dalam Pembelajaran Bahasa Inggris. Psympathic : Jurnal Ilmiah Psikologi 4(2), 219-238.

Uzuntiryaki-Kondakci, E., \& Senay, A. (2015). Predicting Chemistry Achievement through Task Value, Goal Orientations, and SelfEfficacy: A Structural Model. Croatian Journal of Education 17(3), 725-753.

Villafañe, S. M., \& Lewis, J. E. (2016). Exploring a measure of science attitude for different groups of students enrolled in introductory college chemistry. Chemistry Education Research and Practice.

Wade, C. dkk. (2007). Psikologi Edisi Kesembilan Jilid 2. Jakarta: Erlangga.

Wahid, S. N. S., Yusof, Y., \& Razak, M. R. (2014). Math Anxiety among Students in Higher Education Level. Chemistry Education Research and Practice 17(4), 973-984.

Woldeamanuel, M., Atagana, H., \& Engida, T. (2013). Students' Anxiety Towards The Learning Of Chemistry In Some Ethiopian Universities. African Journal of Chemical Education 3(2), 28-38.

Yaman, H. (2010). Writing Anxiety of Turkish Students: Scale Development and the Working Procedures in Terms of Various Variables. International Online Journal of Educational Sciences 2(1), 267-289. 